\title{
PERBEDAAN HASIL PEMERIKSAAN JUMLAH LEUKOSIT ANTARA METODE MANUAL IMPROVED NEUBAUER DENGAN METODE AUTOMATIC HEMATOLOGY ANALYZER
}

\author{
Satya Darmayani, Fonnie E. Hasan, Devi Ekafitria A \\ Jurusan Analis Kesehatan Poltekkes Kemenkes Kendari
}

\begin{abstract}
Leucocytes are nucleated cells in the blood that can be divided into 5 types. Every cell can be calculated its percentage in the blood by doing types calculation and can be distinguished by the size of the core form, color of granules and cytoplasm inside. This study aimed to determine the results of the difference calculation of leukocytes count examination between Manual Method (Improved Neubauer) and Automatic Hematology Analyzer Method in outpatients at the General Hospital of Kendari. Samples of this study were 30 people taken by accidental sampling. The results of the study with 30 samples using manual method (Improved Neubauer), 25 patients (83.4\%) had normal leukocyte and 5 patients (16.6\%) had abnormal, and examination using Automatic Hematology Analyzer Method showed 22 patients (73.4\%) had normal leukocyte and 8 patients $(26.6 \%)$ had abnormal. Based on paired test of samples obtained $p$ value $=0,000$, so it can be concluded that there is significant difference between count examination of leukocytes using Manual Method with Improved Neubauer and Automatic Hematology Analyzer Method.
\end{abstract}

\section{Keyword: Leukocytes, Manual Improved Neubauer, Automatic Hematology Analyzer.}

\section{PENDAHULUAN}

Pemeriksaan darah rutin lengkap merupakan pemeriksaan yang sering diminta oleh klinisi karena dengan melakukan pemeriksaan darah lengkap rutin dapat terdiagnosis beberapa penyakit kelainan darah dan dapat ditentukan arah pemeriksaan lebih lanjut dari penderita tersebut. Pemeriksaan darah rutin antara lain adalah uji kadar hemoglobin; jumlah eritrosit, leukosit, trombosit; nilai hematokrit, laju endap darah disingkat LED dan menentukan indeks eritrosit (Verbrugge \& Huisman 2015), (Rabinovitch et al. 2010), (Lima-oliveira et al. 2013).

Menghitung sel-sel darah dari ketiga jenis sel darah leukosit, eritrosit, dan trombosit dihitung jumlahnya persatuan volume darah. Upaya itu biasanya dilakukan dengan menggunakan alat hitung elektronik.Pada dasarnya alat semacam itu yang lazimnya dipakai bersama alat pengencer otomatik memberi hasil yang sangat teliti dan tepat.Harga alat penghitung elektronik mahal dan mengharuskan pemakaian dan pemeliharaan yang sangat cermat. Selain itu perlu ada upaya untuk menjamin tepatnya alat itu bekerja dalam satu program jaminan mutu (quality control). Cara-cara menghitung sel darah secara manual dengan memakai pipet dan kamar hitung tetap menjadi upaya dalam laboratorium (Ratwita 2007), (Bureau 2012), (Ernst et al. 2008).

Pemeriksaan hitung jumlah leukosit merupakan pemeriksaan darah rutin yang dilakukan di laboratorium klinik. Karena seringnya permintaan pemeriksaan hitung jumlah leukosit, untuk menghitung leukosit secara manual akan memakan waktu yang cukup lama dan kurang cepat, maka dilakukan pemeriksaan hitung jumlah leukosit secara automatik yang mana alat ini menggunakan aliran listrik dengan prinsip impedansi. Walaupun harga mesin automatik cukup mahal, namun alat ini mampu memeriksa dengan cepat, tepat dan mudah (Katrina et al. 2015), (Carraro et al. 2015).

Terutama pada Rumah sakit Umum Daerah Kota Kendari tiap bulan mengalami peningkatan pemeriksaan hitung jumlah leukosit pada awal tahun 2016 bulan januari jumlah pemeriksaan sebanyak 200 , pada bulan februari sebanyak 1175 , sedangkan pada bulan maret 1521 pemeriksaan.

Dengan metode perhitungan yang berbeda (cara manual dan cara automatik) tentunya akan menimbulkan variasi hasil perhitungan sel leukosit. Sebagai contoh Hidayah (2002) mengemukakan bahwa dengan metode manual dan automatik diketahui kekurangan dan kelebihan dari kedua metode 
tersebut, yang tentunya masing-masing metode memiliki keterbatasan.

Dari uraian permasalahan tersebut maka perlu dilakukan penelitian tentang perbedaan hasil perhitungan pemeriksaan hitung jumlah leukosit cara manual metode kamar hitung (Improved neubauer) dengan menggunakan alat automatik hematologi analyzer.

\section{METODE}

\section{Jenis Penelitian}

Penelitian ini bersifat analitik yaitu melakukan pemeriksaan hitung jumlah leukosit menggunakan kamar hitung (Improved Neubauer) dengan alat Automatik Hematologi Analyzer.

\section{Waktu dan Lokasi Penelitian}

Penelitian ini dilaksanakan pada bulan Juni tahun 2016 di Laboratorium Rumah Sakit Umum Daerah (RSUD) Kota Kendari

\section{Populasi dan Sampel}

Populasi dalam penelitian ini adalah pasien rawat jalan yang datang melakukan pemeriksaan darah Rutin di Laboratorium RSUD Kota Kendari. Sampel dalam penelitian ini adalah pasien rawat jalan yang melakukan pemeriksaan leukosit di Laboratorium RSUD Kota Kendari, yang diambil darahnya sebanyak 30 sampel secara Accidental Sampling.

\section{Teknik Pengumpulan Data}

Pengumpulan data dilakukan dengan cara mencatat hasil pemeriksaan hitung jumlah leukosit metode manual improved neubauer dengan metode automatic hematology analyzer di RSUD Kota Kendari.

\section{Analisa data}

Hasil penelitian disajikan dalam bentuk tabel. Untuk melihat ada tidaknya perbedaan, maka dilakukan pengujian statistik Paired Sample Correlation pada tingkat kepercayaan $95 \%(\alpha=$ $0,05)$ dengan kriteria penerimaan dan penolakan: Jika Ho diterima dan Ha ditolak, maka tidak ada perbedaan. Sedangkan Jika Ho ditolak dan Ha diterima, maka ada perbedaan.

\section{Penyajian Data}

Data dalam penelitian ini diolah dan di sajikan dalam bentuk tabel dan diuraikan dalam bentuk narasi.

\section{HASIL PENELITIAN}

Telah dilakukan penelitian terhadap 30 sampel darah, pada perbedaan hasil pemeriksaan hitung jumlah leukosit antara metode manual improved neubauer dengan metode automatic hematology analyzer pada pasien rawat jalan yang telah dilakukan pada Juni 2016 di laboratorium Rumah Sakit Umum Daerah Kota Kendari, diperoleh hasil sebagai berikut:

Tabel 1. Distribusi Hasil Pemeriksaan Hitung Jumlah Leukosit antara Metode Manual Improved Neubauer dengan Metode Automatic Hematology Analyzer di Rumah Sakit Umum Daerah Kota Kendari

\begin{tabular}{cccccccc}
\hline \multirow{2}{*}{ No } & Hasil penelitian & \multicolumn{2}{c}{ Manual } & \multicolumn{2}{c}{ Automatic } & \multicolumn{2}{c}{ Jumlah } \\
\cline { 3 - 8 } & Normal & n & \% & n & $\%$ & N & \% \\
\hline 1 & 25 & 83,4 & 22 & 73,4 & 47 & 78,4 \\
2 & Tidak normal & 5 & 16,6 & 8 & 26,6 & 13 & 21,6 \\
& Total & 30 & 100 & 30 & 100 & 60 & 100 \\
\hline
\end{tabular}

Berdasarkan tabel 1, hasil penelitian secara manual dengan 30 sampel yang memiliki hitung jumlah leukosit normal sebanyak 25 pasien $(83,4 \%)$ sedangkan yang tidak normal sebanyak 5 pasien $(16,6 \%)$, dan penelitian secara automatic hematology analyzer yang memiliki hitung jumlah leukosit normal sebanyak 22 pasien $(73,4 \%)$ sedangkan yang tidak normal sebanyak 8 pasien $(26,6 \%)$. Dan keseluruhan distribusi menujukkan bahwa hasil hitung jumlah leukosit yang normal sebanyak $47(78,4 \%)$ dan yang tidak normal sebanyak 13 $(21,6 \%)$.

\section{PEMBAHASAN}

Dari tabel 1 dapat disimpulkan bahwa dari kedua metode tersebut, metode automatic hematology analyzer mampu menghitung jumlah leukosit lebih presisi dan akurat dimana dengan menggunakan metode atutomatic 
hematology analyzer tidak terjadi kesalahan sehingga pasien tidak dirugikan dengan kesalahan interprestasi hasil seperti positif palsu atau negative palsu. Dari pengujian data menggunakan uji paried sampel didapatkan hasil, nilai $\mathrm{p}=0,000$, maka dapat disimpulkan bahwa Ho diterima dan Ha ditolak, jadi ada perbedaan hasil hitung jumlah leukosit secaramanual improved neubauer dengan automatic hematology analyzer.

Hasil penelitian ini sejalan dengan hasil penelitian yang dilakukan oleh (Hidayah 2002) yang menyatakan bahwa rata-rata hasil pemeriksaan hitung jumlah leukosit secara manual dengan menggunakan Haemositometer adalah $8604 / \mathrm{mm}^{3}$, hasil pemeriksaan hitung jumlah leukosit cara automatik menggunakan alat BC-2600 Auto Hematology Analyzer adalah $7720 / \mathrm{mm}^{3}$ yang menyatakan bahwa ada perbedaan antara hasil pemeriksaan hitung jumlah leukosit secara manual dan automatik.

Dari hasil penelitian ini dengan menggunakan uji paried sampel yang menunjukan hasil nilai rata-rata pada alat automatic hematology analyzer sebesar $8070 / \mathrm{mm}^{3}$ sedangkan pada alat manual improved neubauer sebesar $7575 / \mathrm{mm}^{3}$.

Dalam perhitungan sel leukosit pada alat manual improved neubauer sangat sulit untuk mengontrol atau mendapat akurasi dan presisinya (Cadena-herrera et al. 2015), disebabkan sel leukosit bercampur dengan kotoran pada objek gelas maka pada waktu pembacaan hitung jumlah leukosit memerlukan waktu yang cukup lama agar diperoleh hasil yang maksimal (Hansen et al. 2006).

Automatic hematology analyzer sebagai salah satu jalan yang bisa ditempuh untuk memaksimalkan pemeriksaan tanpa tergantung pada tenaga ahli diciptakan suata alat yang bisa dioprasikan secara sederhana dengan kata lain automatic hematology analyzer dirancang untuk tenaga ahli yang tanpa membutuhkan keterampilan khusus. Alat automatic hematology analyzer ini dirancang sebagai alat yang memiliki akurasi hasil yang mudah dievaluasi karena akurasi dan presisinya bisa dikontrol, jumlah sel yang dihitung lebih banyak dan pembacaan sampel pemeriksaan hanya memerlukan waktu yang singkat sampai pada hasil yang diinginkan.

\section{KESIMPULAN}

1. Hasil hitung jumlah leukosit menggunakan metode manual improved neubauer sebanyak 25 orang $(83,4 \%)$ pasien memiliki hitung jumlah leukosit normal dan sebanyak 5 orang $(16,6 \%)$ pasien memiliki hitung jumlah leukosit tidak normal.

2. Hasil hitung jumlah leukosit menggunakan metode automatic hematology analyzer sebanyak 22 orang $(73,4 \%)$ pasien memiliki hitung jumlah leukosit normal dan sebanyak 8 orang $(26,6 \%)$ pasien memiliki hitung jumlah leukosit tidak normal.

3. Dari dua metode perbedaan pemeriksaan hitung jumlah leukosit dengan metode manual improved neubauer dan metode automatic hematology analyzer menunjukkan bahwa ada perbedaan yang signifikan antara kedua metode.

\section{DAFTAR PUSTAKA}

Bureau, B.S. (2012). International Standard quality and competence, Medical laboratories-Requirements for Quality and Competence.

Cadena-herrera, D. et al. (2015). Validation of Three Viable-Cell Counting Methods: Manual, Semi-Automated, and Automated. Biotechnology Reports. Available at: http://dx.doi.org/10.1016/ j.btre.2015.04.004.

Carraro, P. et al. (2015). Complete Blood Count at the ED: Preanalytic Variables for Hemoglobin and Leukocytes. American Journal of Emergency Medicine. Available at: http://dx.doi.org/10.1016/ j.ajem.2015.05.011.

Ernst, D.J. et al. (2008). Procedures and Devices for the Collection of Diagnostic Capillary Blood Specimens; Approved Standard-Sixth Edition. Clinical And Laboratory Standards Institute, 28(25).

Hansen, C. et al. (2006). Comparison of FACSCount AF System, Improved Neubauer Hemocytometer, Corning 254 Photometer, SpermVision, UltiMate and Nucleo Counter SP-100 for Determination of Sperm Concentration of Boar Semen. Theriogenology, 66, pp. 2188-2194.

Hidayah, I. (2002). Perbedaan Hasil Pemeriksaan Hitung Jumlah Leukosit Secara Manual dan Automatic. Muhammadiyah Semarang.

Katrina, R. et al. (2015). A Comparison of Differential Leucocyte Counts Measured by Conventional Automated Venous Haematology and Darkfield Microscopic 
Examination of Fresh Capillary Blood. Advances in Integrative Medicine, pp.15. Available at: http://dx.doi.org/ 10.1016/j.aimed.2015.05.001.

Lima-oliveira, G. et al. (2013). Original papers. Biochemia Medica, 23(3), pp.308-315.

Rabinovitch, A. et al. (2010). Validation, Verification, and Quality Assurance of Automated Hematology Analyzers; Approved Standard-Second Edition. Clinical And Laboratory Standards
Institute, 30 (June).

Ratwita, G. (2007). Penuntun Laboratorium Klinik, Jakarta: Dian Rakjat.

Verbrugge, S.E. \& Huisman, A. (2015). Verification and Standardization of Blood Cell Counters for Routine Clinical Laboratory Tests. Clinics in Laboratory Medicine, 35(1), pp.183-196. Available at: http://dx.doi.org/10.1016/ j.cll.2014. 10.008 . 